\title{
SURVEI PELAKSANAAN PEMBELAJARAN PENDIDIKAN JASMANI ADAPTIF DI SLB C PROVINSI DKI JAKARTA TAHUN 2019
}

\author{
Slamet Sukriadi \\ Muhamad Arif
}

\author{
Fakultas Ilmu Olahraga, Universitas Negeri Jakarta \\ slametsukriadi@unj.ac.id \\ m.arif@unj.ac.id
}

\begin{abstract}
ABSTRAK
Penelitian ini bertujuan untuk mengetahui pelaksanaan pembelajaran Pendidikan Jasmani Adaptif di SLB C Provinsi DKI Jakarta yang dilihat dari factor tujuan pembelajaran, materi pembelajaran, kompetensi guru, sarana dan prasarana serta evaluasi pembelajaran. Penelitian ini merupakan penelitian deskriptif kuantitatif. Metode yang digunakan adalah survei. Populasi dan sampel penelitian ini adalah 36 guru Pendidikan Jasmani Adaptif SLB C di Provinsi DKI Jakarta. Variable penelitian ini adalah pelaksanaan pembelajaran Pendidikan Jasmani Adaptif di SLB C Provinsi DKI Jakarta data dikumpulkan dengan menggunakan Instrumen yang berupa kuesioner berjumlah 29 butir pertanyaan. Teknik analisis data menggunakan deskriptif kuantitatif.

Hasil penelitian menunjukkan bahwa pelaksanaan pembelajaran Pendidikan Jasmani Adaptif SLB C Provinsi DKI Jakarta tahun 2019 sebanyak 6,67\% dalam kategori tidak baik, 16,67\% dalam kategori kurang baik, 38,89 kategori cukup, 36,11\% dalam kategori baik dan $1,67 \%$ dalam kategori sangat baik. Dengan demikian dapat disimpulkan bahwa Pelaksanaan Pembelajaran Pendidikan Jasmani Adaptif di SLB C Provinsi DKI Jakarta tahun 2019 dalam kategori cukup.
\end{abstract}

\section{Kata kunci: Pembelajaran, Pendidikan Jasmani Adaptif, SLB C}

\section{ABSTRACT}

This study aims to determine the implementation of Adaptive Physical Education learning in SLB C DKI Jakarta Province which is seen from the factors of learning objectives, learning materials, teacher competencies, facilities and infrastructure as well as learning evaluation. This research is quantitative descriptive. The method used is a survey. The population and sample of this study were 36 Adaptive Physical Education teachers of C-SLB in DKI Jakarta Province. The variable of this research is the implementation of Adaptive Physical Education learning in SLB C DKI Jakarta Province data were collected using an instrument in the form of a questionnaire totaling 29 questions. Data analysis techniques using quantitative descriptive.

The results showed that the implementation of Adaptive Physical Education learning SLB C in DKI Jakarta Province in 2019 was $6.67 \%$ in the bad category, 16.67\% in the poor category, 38.89 adequate category, $36.11 \%$ in the good category and $167 \%$ in the excellent category. Thus it can be concluded that the Implementation of Adaptive Physical Education Learning in SLB C DKI Jakarta Province in 2019 is in the sufficient category.

Keywords: Learning, Adaptive Physical Education, SLB C 


\section{PENDAHULUAN}

Pendidikan di Indonesia ditujukan untuk semua orang mulai dari anak kecil sampai orang tua bahkan bagi para penyandang disabilitas, Pendidikan bukan hanya berasal dari bangku sekolah, namun juga dapat berasal dari interaksi sosial yang terjadi dalam kehidupan bermasyarakat. Selain itu pendidikan tidak membatasi dalam hal usia karena pendidikan ditujukan untuk semua kalangan dan semua umur. Tidak semua anak dilahirkan dalam keadaan sempurna, ada juga anak kecil yang mengalami hambatan-hambatan baik dalam perkembangan fisik maupun perkembangan mentalnya. Anak yang demikian diklasifikasikan sebagai Anak Berkebutuhan Khusus (ABK).

Anak berkebutuhan khusus mempunyai hak yang sama dengan anak normal dalam memperoleh pendidikan dan pembelajaran dalam setiap jenjang pendidikan (Beltasar Tarigan, 2008: 14). ABK sama halnya dengan anak-anak normal yang memerlukan penjagaan atau pemeliharaan, pembinaan, asuhan, dan didikan yang sempurna sehingga ABK dapat menjadi manusia yang berdiri sendiri tanpa menyandarkan diri pada pertolongan orang lain.

Pendidikan untuk anak berkebutuan khusus membutuhkan suatu pola layanan tersendiri dengan perkembangan fungsional (children with development impairment), diharapkan perkembangan mengacu kepada suatu kondisi tertentu dengan adanya intelegensi dan fungsi adaptif, dengan menunjukan berbagai masalah dengan kasus-kasus yang berbeda (Bandi Delphie, 2007: 145). Pendidikan bagi anak berkebutuhan khusus bisa dilakukan di keluarga, masyarakat, dan sekolah. Pendidikan formal bagi anak berkebutuhan khusus biasanya diberikan oleh yayasan atau sekolah luar biasa (SLB).

Anak berkebutuhan khusus memerlukan kurikulum, tenaga pendidik, dan sarana prasarana khusus yang telah disesuaikan dengan jenis ketunaan anak Berdasarkan hasil observasi yang dilakukan oleh mahasiswa mata kuliah Pendidikan Jasmani
Adaptif di beberapa SLB yang ada di Jakarta guna memenuhi tugas mata kuliah Pendidikan Jasmani Adaptif, diperoleh informasi bahwa proses pembelajaran pendidikan jasmani adaptif masih menemui beberapa kendala, seperti: (a) minimnya sarana prasarana yang menunjang proses pembelajaran pendidikan jasmani, (b) pelaksanaan penjas adaptif masih menggabungkan peserta didik dari berbagai jenis ketunaan; (c) beberapa guru yang masih belum mengetahui materi apa yang seharusnya diberikan untuk anak sesuai dengan ketunaannya; (d) Latar belakang guru bukan dari Pendidikan Jasmani, tentunya ini akan mengakibatkan pelaksanaan pembelajaran Pendidikan Jasmani yang dilaksanakan kurang sesuai dengan kebutuhan ABK.

Adaptif merupakan kata dari bahasa Inggris "adapt" yang mempunyai arti "menyesuaikan dengan". Menurut Elli Sari (2013: 89), pembelajaran adaptif bagi anak berkebutuhan khusus merupakan pembelajaran yang menyesuaikan dengan kondisi siswa. Artinya yang menyesuaikan adalah pembelajaran itu sendiri, baik metode, alat/media pembelajaran, dan lingkungan belajar bukan siswanya. Pembelajaran adaptif adalah bagaimana meminimalisir kekurangan yang dimiliki peserta didik sehingga kekurangannya ditekan sedemikian rupa kemudian didorong kemampuannya agar berkembang semaksimal mungkin.

Pembelajaran adaptif harus dapat memperbaikI atau meminimalisir dampak dari kelainan yang dimiliki peserta didik, bukan memperburuk kondisi peserta didik (Elli Sari, 2013: 85). Sejalan dengan pemikiran tersebut Irham (2003) dalam Elli Sari (2013: 89) menyebutkan bahwa pembelajaran adaptif merupakan pembelajaran biasa yang dimodifikasi dan dirancang sedemikian rupa sehingga dapat dipelajari, dilaksanakan dan memenuhi kebutuhan pendidikan Anak Berkebutuhan Khusus (ABK).

Anak Berkebutuhan Khusus (ABK) memilki masalah dalam sensorisnya, 
motoriknya, belajarnya dan tingkah lakunya. Semua ini mengakibatkan terganggunya perkembangan fisik anak. Hal ini karena sebagian besar ABK mengalami hambatan dalam merespon rangsangan yang diberikan lingkungan untuk melakukan gerak, meniru gerak dan bahkan ada yang memang fisiknya terganggu sehingga anak tidak dapat melakukan gerakan yang terarah dan benar.

Pembelajaran Pendidikan Jasmani Adaptif memiliki ciri khusus yang membedakan dengan pembelajaran lainnya. Adapun ciri program pengajaran Pendidikan Jasmani Adaptif menurut Asep dan Yani (2013: 25) adalah: 1) Program pengajaran Penjas Adaptif disesuaikan dengan jenis dan karateristik kelainan siswa. Hal ini dimaksudkan untuk memberikan kesempatan kepada siswa yang berkelainan berpartisipasi dengan aman, sukses, dan memperoleh kepuasan. Misalnya bagi siswa yang memakai kursi roda satu tim dengan yang normal dalam bermain basket, ia akan dapat berpartisipasi dengan sukses dalam kegiatan tersebut apabila aturan yang dikenakan kepada peserta didik yang berkursi roda dimodifikasi. 2) Program pengajaran Penjas Adaptif harus dapat membantu dan mengkoreksi kelainan yang disandang oleh peserta didik. Kelainan pada Anak Luar Biasa terjadi pada kelainan fungsi postur, sikap tubuh dan pada mekanika tubuh. Untuk itu, program pengajaran Pendidikan Jasmani Adaptif harus dapat membantu siswa melindungi diri sendiri dari kondisi yang memperburuk keadaannya. 3) Program pengajaran Penjas Adaptif harus dapat mngembangkan dan meningkatkan kemampuan jasmani individu ABK.Untuk itu Pendidikan Jasmani Adaptif mengacu pada suatu program kesegaran jasmani yang progressif, selalu berkembang dan atau latihan otot-otot besar. Dengan demikian tingkat perkembangan $\mathrm{ABK}$ akan dapat mendekati tingkat kemampuan teman sebayanya. Apabila program Pendidikan Jasmani Adaptif dapat mewujudkan hal tersebut diatas, maka Penjas Adaptif dapat membantu peserta didik melakukan penyesuaian sosial dan mengembangkan perasaan siswa memiliki harga diri.

Pembelajaran Pendidikan Jasmani Adaptif bagi anak berkebutuhan khusus tidak serta merta sebagai wujud pelaksanan kurikulum. Lebih lanjut lagi Penjas Adaptif bertujuan untuk membantu ABK mencapai pertumbuhan dan perkembangan jasmani, mental, emosional dan sosial yang sepadan dengan potensi $\mathrm{ABK}$ melalui program aktivitas jasmani biasa dan khusus yang dirancang dengan hati-hati (Arma Abdoellah, 1996: 4). Pendidikan Jasmani anak berkebutuhan khusus berbeda dengan pendidikan jasmani anak normal pada umumnya. Perbedaaan pendidikan anak berkebutuhan khusus dengan anak normal dapat dilihat dari tujuan pembelajaran yang dicapai, modifikasi materi yang diajarkan, sarana prasarana, dan evaluasi pembelajaran oleh karena itu sangat menarik bila diketahui pelaksanaan pembelajaran Pendidikan Jasmani sebagaimana penelitian yang telah dilakukan oleh Andi Sutonda S dkk, yang berjudul Kemampuan Guru Pendidikan Jasmani Adaptif dalam Melaksanakan Program Pembelajaran di SLB Bagian A Kota Bandung yang bertujuan mengetahui bagaimana keterampilan guru Pendidikan jasmani dalam membuka pembelajran, mengelola aktivitas pembelajaran, menutup pembelajaran, menggunakan metode pembelajaran, menggunakan peralatan pada saat pembelajaran dan mengevaluasi pada pembelajaran. Penelitian tersebut menjelaskan bahwa keterampilan guru Pendidikan jasmani adaptif yang masih kurang.

\section{METODE PENELITIAN}

Penelitian ini merupakan penelitian deskriptif. Metode yang digunakan dalam penelitian ini adalah survei, sedangkan teknik pengumpulan data menggunakan angket. metode survei merupakan penelitian yang biasa dilakukan dengan subjek yang banyak, dimaksudkan untuk mengumpulkan pendapat atau informasi mengenai status gejala pada waktu penelitian berlangsung. Penelitian ini 
berlangsung dari bulan Mei sampai dengan Oktober tahun 2019.

Populasi penelitian ini adalah guru-guru SLB C di DKI Jakarta yang berjumlah 36 orang. Teknik pengambilan sampel menggunakan total sampling sehingga seluruh populasi dijadikan sampel penelitian ini. Pengumpulan data pada penelitian ini menggunakan metode survei, data yang dikumpulkan berupa Data SLB C di DKI Jakarta melalui Dinas Pendidikan Provinsi DKI Jakarta.

\section{HASIL PENELITIAN}

Hasil dari penelitian ini dideskripsikan dari setiap faktor dan subjek penelitian yang diteliti. Faktor pelaksanaan pembelajaran yaitu tujuan pembelajaran penjas adaptif, materi pembelajaran penjas adaptif, kompetensi guru, sarana dan prasarana penjas adaptif, dan evaluasi pembelajaran penjas adaptif.

Tabel 1.

Distribusi Frekuensi pelaksanaan pembelajaran Pendidikan Jasmani Adaptif di SLB C Provinsi DKI Jakarta tahun 2019

\begin{tabular}{cccc}
\hline Interval & Kategori & Frek & \% \\
\hline $\mathrm{X}>28,04$ & $\begin{array}{c}\text { Sangat } \\
\text { Baik }\end{array}$ & 1 & 3 \\
\hline $\begin{array}{c}25,81<\mathrm{X} \\
\leq 28,04\end{array}$ & Baik & 13 & 36 \\
\hline $\begin{array}{c}23,58<\mathrm{X} \\
\leq 25,81\end{array}$ & Cukup & 12 & 33 \\
\hline $\begin{array}{c}21,35<\mathrm{X} \\
\leq 23,58\end{array}$ & $\begin{array}{c}\text { Kurang } \\
\text { Baik }\end{array}$ & 7 & 19 \\
\hline $\mathrm{X} \leq 21,35$ & $\begin{array}{c}\text { Tidak } \\
\text { Baik }\end{array}$ & 3 & 8 \\
\hline \multicolumn{2}{c}{ Total } & 36 & 100 \\
\hline
\end{tabular}

Tabel di atas menunjukkan pelaksanaan pembelajaran Pendidikan Jasmani Adaptif di SLB C Provinsi DKI Jakarta tahun 2019 menyatakan bahwa sebanyak 1 responden atau 3\% dalam kategori sangat baik, 13 responden atau 36\% dalam kategori baik, 12 responden atau $33 \%$ dalam kategori cukup, 7 responden atau $19 \%$ dalam kategori kurang baik dan 3 responden atau 8\% dalam kategori tidak baik. Responden terbanyak terdaat dalam interval $25,81<\mathrm{X}$ $\leq 28,04$. Dapat disimpulkan bahwa pelaksaan pembelajaran Pendidikan Jasmani Adaptif di SLB C Provinsi DKI Jakarta tahun 2019 dalam kategori baik.

Tabel 2. Distribusi Frekuensi pelaksanaan pembelajaran Pendidikan Jasmani Adaptif di SLB C Provinsi DKI Jakarta tahun 2019 Faktor Tujuan Pembelajaran.

\begin{tabular}{|c|c|c|c|}
\hline Interval & Kategori & Frekuensi & $\%$ \\
\hline$X>6,73$ & $\begin{array}{l}\text { Sangat } \\
\text { Baik }\end{array}$ & 0 & 0 \\
\hline $\begin{array}{c}5,89<X \\
\leq 6,73\end{array}$ & Baik & 24 & 67 \\
\hline $\begin{array}{c}5,05<X \\
\leq 5,89\end{array}$ & Cukup & 0 & 0 \\
\hline $\begin{array}{c}4,21<X \\
\leq 5,05\end{array}$ & $\begin{array}{l}\text { Kurang } \\
\text { Baik }\end{array}$ & 6 & 17 \\
\hline$X \leq 4,21$ & $\begin{array}{l}\text { Tidak } \\
\text { Baik }\end{array}$ & 6 & 17 \\
\hline \multicolumn{2}{|c|}{ Total } & 36 & 100 \\
\hline
\end{tabular}

Tabel di atas menunjukkan pelaksanaan pembelajaran Pendidikan Adaptif berdasarkan faktor tujuan pembelajaran. sebanyak 0 responden atau 0\% dalam kategori sangat baik, 24 responden atau $67 \%$ dalam kategori baik, 0 responden atau $0 \%$ dalam kategori cukup, 6 responden atau $17 \%$ dalam kategori kurang baik dan kategori tidak baik. Responden terbanyak terdapat dalam interval $5,89<\mathrm{X}$ $\leq$ 6,73. Dapat disimpukan bahwa pelaksanaan pembelajaran Pendidikan Jasmani Adaptif di SLB C Provinsi DKI Jakarta tahun 2019 berdasarkan faktor tujuan pembelajaran dalam kategori baik

Tabel 3. Distribusi Frekuensi pelaksanaan pembelajaran Pendidikan Jasmani Adaptif di SLB C Provinsi DKI Jakarta tahun 2019 Faktor Materi Pembelajaran 


\begin{tabular}{lccc}
\hline \multicolumn{1}{c}{ Interval } & Kategori & FreK & \% \\
\hline$X>4,34$ & Sangat Baik & 3 & 8 \\
\hline $\begin{array}{l}3,50<X \leq \\
4,34\end{array}$ & Baik & 5 & 14 \\
\hline $\begin{array}{l}2,66<X \leq \\
3,50\end{array}$ & Cukup & 20 & 56 \\
\hline $\begin{array}{l}1,82<X \leq \\
2,66\end{array}$ & Kurang Baik & 8 & 22 \\
\hline$X \leq 1,82$ & Tidak Baik & 0 & 0 \\
\hline \multicolumn{1}{r}{ Total } & 36 & \multicolumn{2}{c}{100} \\
\hline
\end{tabular}

Tabel di atas menunjukkan pelaksanaan pembelajaran Pendidikan Adaptif berdasarkan faktor materi pembelajaran. sebanyak 3 responden atau $8 \%$ dalam kategori sangat baik, 5 responden atau $14 \%$ dalam kategori baik, 20 responden atau $56 \%$ dalam kategori cukup, 8 responden atau $22 \%$ dalam kategori kurang baik dan 0 responden dan $0 \%$ dalam kategori tidak baik. Responden terbanyak terdapat dalam interval 2,66 $<\mathrm{X} \leq 3,50$. Dapat disimpukan bahwa pelaksanaan pembelajaran Pendidikan Jasmani Adaptif di SLB C Provinsi DKI Jakarta tahun 2019 berdasarkan faktor materi pembelajaran dalam kategori cukup.

Tabel 4. Distribusi Frekuensi pelaksanaan pembelajaran Pendidikan Jasmani Adaptif di SLB C Provinsi DKI Jakarta tahun 2019 Faktor kompetensi guru.

\begin{tabular}{|c|c|c|c|}
\hline Interval & Kategori & Frek & $\%$ \\
\hline$X>6,51$ & $\begin{array}{l}\text { Sangat } \\
\text { Baik }\end{array}$ & 0 & 0 \\
\hline $\begin{array}{c}6,06<X \\
\leq 6,51\end{array}$ & Baik & 0 & 0 \\
\hline $\begin{array}{c}5,61<X \\
\leq 6,06\end{array}$ & Cukup & 31 & 86 \\
\hline $\begin{array}{c}5,16<X \\
\leq 5,61\end{array}$ & $\begin{array}{c}\text { Kurang } \\
\text { Baik }\end{array}$ & 4 & 11 \\
\hline$X \leq 5,16$ & $\begin{array}{l}\text { Tidak } \\
\text { Baik }\end{array}$ & 1 & 3 \\
\hline \multicolumn{2}{|c|}{ Total } & 36 & 100 \\
\hline
\end{tabular}

Tabel di atas menunjukkan pelaksanaan pembelajaran Pendidikan Adaptif berdasarkan faktor kompetensi guru. sebanyak 0 responden atau $0 \%$ dalam kategori sangat baik, 0 responden atau $0 \%$ dalam kategori baik, 31 responden atau 86\% dalam kategori cukup, 4 responden atau $11 \%$ dalam kategori kurang baik dan 1 responden dan 3\% dalam kategori tidak baik. Responden terbanyak terdapat dalam interval 5,61 $<\mathrm{X} \leq 6,06$. Dapat disimpukan bahwa pelaksanaan pembelajaran Pendidikan Jasmani Adaptif di SLB C Provinsi DKI Jakarta tahun 2019 berdasarkan faktor kompetensi guru dalam kategori cukup.

Tabel 5. Distribusi Frekuensi pelaksanaan pembelajaran Pendidikan JasmaniAdaptif di

SLB C Provinsi DKI Jakarta tahun 2019 Faktor sarana dan prasarana.

\begin{tabular}{|c|c|c|c|}
\hline Interval & Kategori & Frekuensi & $\%$ \\
\hline$X>5,91$ & $\begin{array}{l}\text { Sangat } \\
\text { Baik }\end{array}$ & 0 & 0 \\
\hline $\begin{array}{c}4,75<X \\
\leq 5,91\end{array}$ & Baik & 19 & 53 \\
\hline $\begin{array}{c}3,59<X \\
\leq 4,75\end{array}$ & Cukup & 9 & 25 \\
\hline $\begin{array}{c}2,43<X \\
\leq 3,59\end{array}$ & $\begin{array}{c}\text { Kurang } \\
\text { Baik }\end{array}$ & 5 & 14 \\
\hline$X \leq 2,43$ & $\begin{array}{l}\text { Tidak } \\
\text { Baik }\end{array}$ & 3 & 8 \\
\hline \multicolumn{2}{|c|}{ Total } & 36 & 100 \\
\hline
\end{tabular}

Tabel di atas menunjukkan pelaksanaan pembelajaran Pendidikan Adaptif berdasarkan faktor sarana dan prasarana. sebanyak 0 responden atau $0 \%$ dalam kategori sangat baik, 19 responden atau $53 \%$ dalam kategori baik, 9 responden atau 25\% dalam kategori cukup, 5 responden atau $14 \%$ dalam kategori kurang baik dan 3 responden dan 8\% dalam kategori tidak baik. Responden terbanyak terdapat dalam interval $4,75<\mathrm{X} \leq 5,91$. Dapat disimpukan bahwa pelaksanaan pembelajaran Pendidikan Jasmani Adaptif di SLB C Provinsi DKI Jakarta tahun 2019 berdasarkan faktor sarana dan prasarana dalam kategori baik 
Tabel 6. Distribusi Frekuensi pelaksanaan pembelajaran Pendidikan Jasmani Adaptif di SLB C Provinsi DKI Jakarta tahun 2019 Faktor Evaluasi Pembelajaran.

\begin{tabular}{|c|c|c|c|}
\hline Interval & Kategori & Frekuensi & $\%$ \\
\hline$X>7,67$ & $\begin{array}{l}\text { Sangat } \\
\text { Baik }\end{array}$ & 0 & 0 \\
\hline $\begin{array}{l}6,65<X \\
\leq 7,67\end{array}$ & Baik & 17 & 47 \\
\hline $\begin{array}{l}5,63<X \\
\leq 6,65\end{array}$ & Cukup & 10 & 28 \\
\hline $\begin{array}{l}4,61<X \\
\leq 5,63\end{array}$ & $\begin{array}{l}\text { Kurang } \\
\text { Baik }\end{array}$ & 7 & 19 \\
\hline$X \leq 4,61$ & $\begin{array}{l}\text { Tidak } \\
\text { Baik }\end{array}$ & 2 & 6 \\
\hline \multicolumn{2}{|c|}{ Total } & 36 & 100 \\
\hline
\end{tabular}

Tabel di atas menunjukkan pelaksanaan pembelajaran Pendidikan Adaptif berdasarkan faktor evaluasi pembelajaran. sebanyak 0 responden atau 0\% dalam kategori sangat baik, 17 responden atau $47 \%$ dalam kategori baik, 10 responden atau $28 \%$ dalam kategori cukup, 7 responden atau $19 \%$ dalam kategori kurang baik dan 2 responden dan $6 \%$ dalam kategori tidak baik. Responden terbanyak terdapat dalam interval $6,65<\mathrm{X}$ $\leq$ 7,67. Dapat disimpukan bahwa pelaksanaan pembelajaran Pendidikan Jasmani Adaptif di SLB C Provinsi DKI Jakarta tahun 2019 berdasarkan faktor evaluasi pembelajaran dalam kategori baik.

\section{PEMBAHASAN}

Berdasarkan hasil penelitian
menunjukkan bahwa pelaksanaan
pembelajaran Pendidikan Jasmani Adaptif
di SLB C Provinsi DKI Jakarta tahun 2019
termasuk dalam kategori baik. Guru- guru
Pendidikan jasmani di SLB C Provinsi DKI
Jakarta sebagian besar sudah melaksanakan
pembelajaran Pendidikan Jasmani Adaptif
di sekolahnya masing-masing dengan
cukup baik.
Pelaksanaan pembelajaran Pendidikan
Jasmani Adaptif di SLB C Provinsi DKI
Jakarta tahun 2019 dilihat dari factor tujuan
pembelajaran adalah baik. Terbukti

sebanyak $67 \%$ guru dalam kategori baik, dan $17 \%$ dalam kategori kurang baik dan 17\% lainnya dalam kategori tidak baik. Guru Pendidikan Jasmani sejatinya harus memahami tujuan pembelajaran yang sesuai dengan kurikulum dan tujuan yang disesuaikan dengan kondisi peserta didik.

Pelaksanaan pembelajaran Pendidikan jasmani adaptif di SLB C Provinsi DKI Jakarta tahun 2019 dilihat dari factor materi pembelajaran dalam kategori cukup. Berdasarkan hasil penelitian bahwa sebanyak $8 \%$ dalam kategori sangat baik, $14 \%$ dalam kategori baik, 56\% dalam kategori cukup, dan 22\% dalam kategori kurang baik. Guru sejatinya harus mengetahui dan menentukan materi yang sesuai dengan kurikulum serta kondisi peserta didik. Pada dasarnya, materi pembelajaran peserta didik berkebutuhan khusus sama dengan peserta didik anak normal hanya saja berbeda dalam pelaksanannya di lapangan.

Pelaksanaan pembelajaran Pendidikan Jasmani Adaptif di SLB C Provinsi DKI Jakarta tahun 2019 dilihat dari factor kompetensi guru adalah cukup. Berdasarkan hasil penelitian bahwa sebanyak $86 \%$ dalam kategori cukup, $11 \%$ dalam kategori kurang baik dan 3\% dalam kategori tidak baik. Pada dasarnya guru harus mempersiapkan pembalajaran dengan baik seperti menyusun rencana pelaksanaan pembelajaran sebelum dimulai, guru juga harus menguasai materi yang akan diberikan. Apabila guru tidak memiliki kompetensi yang harus dimiliki ketika mengajar anak berkebutuhan khusus maka pembelajaran tidak bias berjalan sebagaimana mestinya.

Pelaksanaan pembelajaran Pendidikan Jasmani Adaptif SLB C Provinsi DKI Jakarta tahun 2019 dilihat dari factor sarana dan prasarana adalah dalam kategori baik. Berdasarkan kepada hasil penelitian bahwa $53 \%$ dalam kategori baik, 25\% dalam kategori cukup $14 \%$ dalam kategori kurang baik dan $8 \%$ dalam kategori tidak baik. Dapat dilihat bahwa dari segi sarana dan prasarana yang mendukung pembelajaran, Provinsi DKI Jakarta telah memiliki sarana 
dan Prasarana yang cukup di masingmasing sekolah.

Pelaksanaan pembelajaran Pendidikan Jasmani Adaptif SLB C Provinsi DKI Jakarta berdasarkan factor evaluasi pembelajaran dalam kategori baik. Dapat dilihat bahwa sebanyak $47 \%$ dalam kategori baik, $28 \%$ dalam kategori cukup, 19\% dalam kategori kurang baik dan $6 \%$ dalam kategori tidak baik. Sejauh ini guru Pendidikan jasmani SLB C Provinsi DKI Jakarta selalu melakukan evaluasi di akhir pembelajaran. Hal tersebut bertujuan untuk mengetahui kelemahan dan kemajuan gerak peserta didik.

\section{KESIMPULAN}

Hasil penelitian menunjukkan bahwa pelaksanaan pembelajaran Pendidikan Jasmani Adaptif SLB C Provinsi DKI Jakarta tahun 2019 sebanyak 6,67\% dalam kategori tidak baik, 16,67\% dalam kategori kurang baik, 38,89 kategori cukup, 36,11\% dalam kategori baik dan $1,67 \%$ dalam kategori sangat baik. Dengan demikian dapa disimpulkan bahwa Pelaksanaan Pembelajaran Pendidikan Jasmani Adaptif di SLB C Provinsi DKI Jakarta tahun 2019 dalam kategori cukup dengan presentase $38,89 \%$.

Dalam melaksanakan penelitian, penulis menyadari akan adanya keterbatasan dan kekurangan penelitian yaitu tanpa didukung dengan adanya prosedur observasi dan wawancara. Peneliti hanya menggunakan jenis instrument penelitian untuk mengumpulkan data yaitu berupa kuesioner yang berupa angket dengan berbagai kelemahan seperti tidak sepenuhnya menggambarkan keadaan yang sebernarnya dari subjek atau responden sehingga dikhawatirkan responden cenderung menjawab apa yang sebaiknya dan bukan apa yang sebenarnya terjadi.

\section{REFERENSI}

Abdul Hadis. (2006). Pendidikan Anak Berkebutuhan Khusus Autistik. Bandung: Alfabeta.
Agus Marsidi. (2007). Profesi Keguruan Pendidikan Luar Biasa. Jakarta: Departemen Pendidikan Nasional.

Andi Suntoda S dan Santi Vidia Andriyani (2011) "Kemampuan Guru Pendidikan Jasmani Adaptif Dalam Melaksanakan Program Pembelajaran Di Slb Bagian A Kota Bandung, Andi Suntoda S dan Santi Vidia Andriyani (Universitas Pendidikan Indonesia)" Upi.edu Jurnal Pendidikan Olahraga

Aqila Smart. (2010). Anak Cacat Bukan Kiamat. Yogyakarta:

Katahati. Bandi Delphie. (2007). Pembelajaran untuk Anak dengan Kebutuhan Khusus. Jakarta: Depdiknas.

Bandi Delphie. (2010). Pembelajarn Anak Tunagrahita. Bandung: PT Refika Aditama.

Beltasar Tarigan. (2000). Penjas Adaptif. Jakarta: Departemen Pendidikan dan Kebudayaan.

Haenudin. (2013). Pendidikan Anak Berkebutuhan Khusus. Jakarta Timur: PT. Luxima Metro Media.

Hari Amirullah. (2011). Keterlaksanaan Pendidikan Jasmani dan Olahraga di Daerah Istimewa Yogyakarta. Jurnal Pendidikan Jasmani Indonesia (Volume 8, Nomor 1, April 2011).

Murtadlo, Sri Widati. (2007). Pembelajaran Pendidikan Jasmani Adaptif. Jakarta: Depdiknas.

Suharsimi Arikunto. (2013). Prosedur Penelitian: Suatu Pendekatan Praktik. Jakarta: PT Rineka Cipta.

Sumaryanti, dkk. (2010). Pengembangan Model Pembelajaran Jasmani Adaptif untuk Optimalisasi Otak Anak Tunagrahita. Jurnal Kependidikan (Volume 40, Nomor 1). Hlm. 29-44. Sutjihati Somantri. (2006). 